DOI:10.17951/h.2020.54.2.53-65

\begin{tabular}{lc}
\hline & A N N A L E S \\
UNIVERSITATIS MARIAE CURIE-SKŁODOWSKA \\
LUBLIN - POLONIA \\
SOL. LIV, 2
\end{tabular}

\author{
ANNA H. MATUSZEWSKA \\ a.matuszewska@pwsz-kalisz.edu.pl \\ The President Stanisław Wojciechowski State University of Applied Sciences. \\ Faculty of Social Sciences \\ 4 Nowy Świat St., 62-800 Kalisz \\ ORCID ID: https://orcid.org/0000_0002-4450-779x
}

\title{
Presentation and Assessment of Provisions of Strategic Documents in the Context of Possibilities of Achieving Key Objectives as Well as the Vision and Mission of the Social Insurance Institution
}

Keywords: ZUS; quality management; customer satisfaction; management by objectives; New Public Management JEL: G22; L26; L32

How to quote this paper: Matuszewska, A.H. (2020). Presentation and Assessment of Provisions of Strategic Documents in the Context of Possibilities of Achieving Key Objectives as Well as the Vision and Mission of the Social Insurance Institution. Annales Universitatis Mariae Curie-Skłodowska, sectio H-Oeconomia, Vol. 54, No. 2

\begin{abstract}
Traditional approach to management based on administration does not guarantee full achievement of its goals, nor is it satisfactory to service recipients. The focus on the widely understood stakeholders of the public domain is of the utmost value within the public sector. Thus, modern approach to management in public administration requires to abandon bureaucracy and improve the quality of services, customer satisfaction, and openness to new technologies. The article focuses on presenting and assessing the essence of changes in the Social Insurance Institution management which are supposed to ensure that the status of a modern public institution will be achieved. The process of transformations was conducive to developing a new model of management which is based on management by objectives, employs process-oriented management, and whose aim is to increase customer satisfaction.
\end{abstract}




\section{Introduction}

Dynamic social-economic transformations, technological progress, innovation focus, and a strong aspiration to improve the quality of the provided services contribute to an inevitable evolution in the way public organizations are managed. Therefore, the directors of public institutions more and more often turn to solutions that have proven themselves in business organizations. In the 1980s and 1990s, first in Great Britain, Australia and New Zealand, then in the USA, a new model of management in the public sector appeared - New Public Management (NPM). The reason why the changes occurred was conclusions which basically demonstrated that organizations based on bureaucratic functioning "took care" of themselves, not the citizens. The assumption that laid the foundations for NPM was the conviction that public institutions must make use of patterns that function and are tested in business - with one very important reservation: maximizing profit should be replaced with minimizing costs related to achieving objectives. Public institution management requires utilizing methods used in the world of business, properly adjusted to the specificity of state administration, of course. After all, the essence of new public management of public institutions means giving priority to the art of management over the art of administration (Zawicki, 2011, p. 39).

The Social Insurance Institution (hereinafter referred to as ZUS) operates under the Act of 13 December 1998 on the social insurance system and is one of the largest public institutions in Poland (Act on the social insurance system, Journal of Laws of 2018, item 1076). ${ }^{1}$ ZUS services over 2.3 million entrepreneurs and provides services to over 24.5 million people. Annually, ZUS receives over 29 million application forms, about 23 million medical leaves, and about 80 million insurance papers (Rzeczpospolita ubezpieczonych..., 2018, p. 75). Therefore, it is justified to discuss its organization and analyze the process of transformations to fully understand and highlight the range of measures taken by ZUS to use modern models of management.

The main aim of this article is to present and assess provisions of strategic documents for the years 2010-2020 in the context of possibilities of achieving strategic objectives which lead to building and strengthening its positive image among customers. This article attempts to prove that ZUS, using available tools and becoming part of new public management, is consistent in implementing new models of management. Research methods used in the article include: document analysis, monographic method, and comparative method. An analysis of ZUS internal documents became the basic research technique which allowed the author to achieve the aim of the article. The research subject is ZUS, whereas the scope of the research is the ZUS area of operation.

1 ZUS is a state organization unit with the status of a legal entity. It provides social insurance services within the territory of the Republic of Poland. 


\section{From bureaucracy to modern management at ZUS}

In the second decade of the $20^{\text {th }}$ century, ZUS introduced modern methods of management based on solutions used in commercial companies. The following strategic documents formed the basis for changes:

- Transformation strategy of the Social Insurance Institution for the years 2010 2012, whose aim was to increase customer satisfaction through introducing innovative solutions in services (Strategia przeksztatceń..., 2010),

- ZUS Development Strategy for the years 2013-2015, which formed the basis for implementing new solutions to increase the quality of consumer service and broaden the range of electronic services (Strategia rozwoju..., 2012),

- ZUS Strategy for the years 2016-2020, which is a continuation of the principles accepted in the previous strategic documents, and sets new, crucial for ZUS, values and development directions (Strategia Zakładu..., 2015).

Before the strategy for the years 2016-2020 was adapted by ZUS, numerous analyses were carried out, including:

- an analysis of strategic documents of the national development in the 2020 and 2030 perspective (Dlugookresowa Strategia..., 2013),

- an analysis of conclusions drawn from the implementation of previous ZUS strategies,

- an analysis of ZUS strengths and weaknesses,

- a study of ZUS external environment.

The aforementioned analyses and a strategic diagnosis made it possible to validate the vision and mission of ZUS, whose exact wording is: "ZUS's vision is to achieve the status of a socially trusted innovative institution", while its mission is: "To effectively and reliably provide, through the use of modern technology and employee potential, a user-friendly service for customers based on the legal regulations in force, on rational principles, and the transparent management of the financial resources" (Strategia Zaktadu..., 2015).

The carried out analyses validated the relevance of ZUS strategic directions connected with facilitating external and internal communication, improving the effectiveness of implementing objectives and processes, rational management of public funds, and improving customer service as well as the quality of the services it provides. ZUS top management is consistent in implementing the chosen strategy and resists the temptation to change it in response to ongoing events. A well-developed strategy allows concentration on the issues which are fundamental for the future of the organization, and is oriented towards the optimal use of internal and external resources (Penc, 1999, p. 585). New directions of measures taken by ZUS are connected with increasing the degree of cooperation and exchange of data and information with other institutions, improving solutions supporting access to managerial information, and providing mechanisms supporting effective achievement 
of objectives, protection of resources and systems, and continuity of ZUS activities (Strategia Zakładu..., 2015).

On the basis of its vision and mission, ZUS strategic objectives were defined for the years 2016-2020 and grouped into four perspectives:

- customer and other stakeholders perspective, which addresses the relations between service providers and recipients,

- internal processes perspective, which concentrates on the way (method) of providing the final product by the organization,

- development perspective, which focuses on resources that allow ZUS to provide services,

- financial perspective, which involves finances of the organization.

Defining objectives in an organization influences concentration of efforts and the feeling of direction. Objectives determine plans and decisions, and facilitate progress assessment (Stoner, Freeman, \& Gilbert, 2001, p. 263). Either succeeding or failing to achieve the predetermined goals is highly dependent on the qualifications, commitment and situation assessment skills of the entire leadership staff.

The map clearly shows that improvement in the customer service standard is the key objective. Measures implemented within this objective will include intensification of all activities aimed at a further increase in the level of customer service in ZUS offices, and broadening the range of issues that will be comprehensively handled during a single visit to the Customer Service Room (sala obstugi klientów, SOK). However, apart from improving traditional forms of contact, ZUS develops and wants to enhance digital services. What is more, its aim is also to guarantee a proper level of maturity of the services provided electronically. ZUS customers, contribution payers, the insured, and service recipients expect efficient, friendly, and reliable services as well as quick access to information.

Figure 1 presents a map of ZUS strategic objectives for the years 2016-2020, which are grouped according to the aforementioned perspectives and broken down into main and specific. The main objectives show directions of changes, while the specific ones clarify them in particular areas of ZUS activity. In the strategy for the years 2016-2020, The Management Board of the Social Insurance Institution accepted its 5-year time horizon because of the complexity of the planned developmental undertakings - the need for stabilization and consolidation of changes - embarked on while implementing previous strategies. 


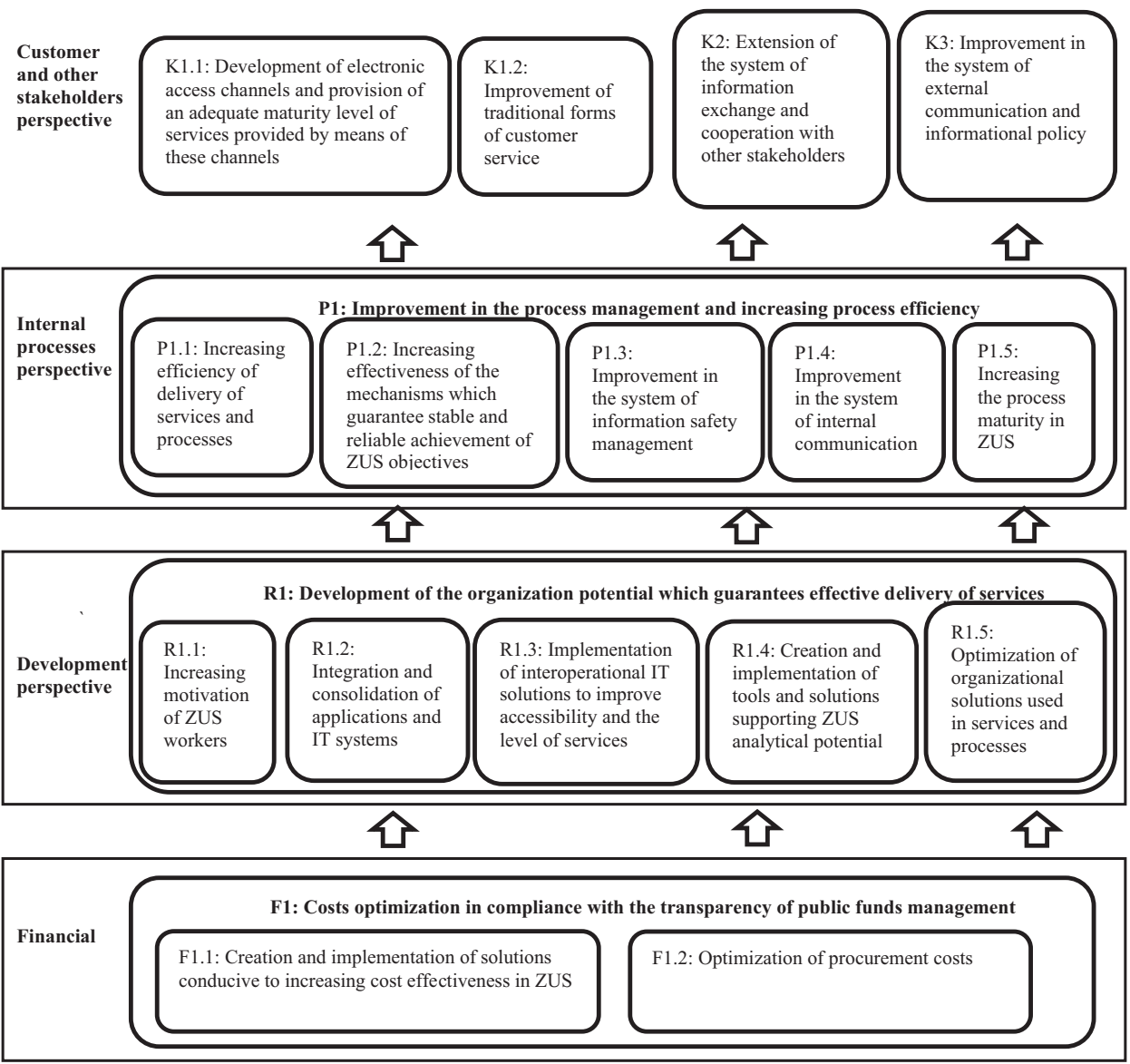

Figure 1. Map of ZUS objectives for the years 2016-2020

Source: (Strategia Zaktadu..., 2015).

Orientation towards objectives means satisfying at least two conditions. The first one refers to cataloging objectives and the other one to achieving objectives at least on the level required by the Act on the social security system. The added value will be the difference between the actual level of the provided service and the level required by the law. The aforementioned value, offered to citizens by ZUS, forms the basis for building customer satisfaction, as evidenced by issuing certificates of no arrears in contribution payments. According to its regulations, ZUS is obliged to issue the certificate within 7 days. In 2010, ZUS introduced a procedure of issuing them "on the spot" (without the need to transfer the case to other referral units), which obviously translated into increased customer satisfaction. The catalogue of issues handled "on the spot" widened successively - according to the data published by ZUS at the end 
of 2017, it comprised 29 issues, including application for insurance, certificate of no arrears in contribution payments, decision of benefit payments, and data modification for benefit payments. In 2017, over 2.3 million $^{2}$ such issues were handled in SOKs. In fact, ZUS orientation towards objectives means orientation towards customers and is achieved through implementing the rule of maximizing customer satisfaction on the level of services provided by the institution (Lewandowska, 2014, p. 14). Customer orientation means optimizing the difference between the required and the actual level of the provided services.

Therefore, it is necessary to measure precisely the activity in both the operational and strategic domain. The results and their thorough analysis form the basis for continual modernization, in accordance with the Deming Cycle. The cycle, created by an American statistician, is a four-stage scheme illustrating the basic rule of continuous improvement:

$-\mathrm{P}$ (Plan),

$-\mathrm{D}(\mathrm{Do})$,

$-\mathrm{C}$ (Check),

$-\mathrm{A}($ Act).

However, Deming's idea was not to use the PDCA only once and with regard to only one activity. Its essence is to strive for improvement in the system of work, improvement in the achieved result, which is to lead to an improvement in the entire organization as a consequence. In its strategy, ZUS indicates objectives and measures broken down by the Balanced Scorecard perspective. The aim is understood as the desired result whose achievement, through common work, is a shared goal of the entire group. In the planning process, top management formulates objectives and informs all the other members of the organization about them, indicating what their activities should be aimed at (Krzakiewicz \& Cyfert, 2015, p. 43). Objectives are necessary to implement a company strategy - without them, the company is like a ship without a compass. The thing is, however, to make sure that setting objectives does not eliminate reason or responsibility, or prevent corrections in the direction which are indispensable in navigating (Blikle, 2013, p. 99).

Efficiency of activities and minimizing the risk of the undesirable phenomenon are largely dependent on the knowledge and acceptance of assumptions used in strategic documents. It is worth noting Kotarbiński's definition of an organization, which he defines as a whole whose components are selected and interrelated so as to contribute to the prosperity of the whole, and the prosperity may be understood in various ways, for instance, depending on the objective set by the organizer (Kotarbiński, 1975a, p. 115). Proper communication and coordination make it possible to find a relation between tasks performed by an employee and objectives of an organization. They also facilitate the understanding of the role they are to play. According

2 Statistical data used in the article were provided to the author by the ZUS Customer Service Department, application 990100/0146/49/2018 of 19 March 2018. Data for the year 2017. 
to Kotarbiński's deliberations in Traktat o dobrej robocie, a genuinely cooperative action is only when there is a common end (Kotarbiński, 1975b, p. 97).

In order to ensure efficient monitoring of its strategy implementation, each ZUS strategic objective was specified more precisely, which meant that a measure and its owner were assigned to each of them. The owner was appointed in accordance with the scope of responsibilities under the Organizational Rules of the Social Insurance Institution defined in the ZUS organizational regulations. The role of the measure owner was to:

- declare the baseline and target level of the index,

- identify the ways of achieving the objective,

- monitor the index value on a regular basis (Strategia Zakładu..., 2015).

Implemented system of measures enables effective institution management due to the fact that measurement results clearly signal which areas need improvement. Measures of the desired target results are commonly defined and reviewed, and final results are commonly assessed (Szymańska, 2015, p. 29). It is a well-known fact to the people in leadership positions that "If you cannot measure something, you cannot manage it" (Garvin, 2006, p. 84). Early risk diagnosis of not achieving the objectives will make it possible to minimize its materialization. Within the framework of risk management implemented in ZUS, actions will be taken to minimize that risk, and in order to define specific results, information about them is indispensable. Therefore, the first step is to measure the actual implementation, compare it with the assumed standards, and, finally, take action to correct deviations from the standards or change wrong standards (Robbins \& DeCenzo, 2002, p. 569).

Referring to the specific aim of this article, Table 1 presents only an analysis of the main objective connected with the customer perspective, which, in the strategy for the years 2013-2015, was defined as customer service improvement. Specific objectives included increasing the degree of digitalizing contact with customers and improvement of traditional forms of customer service (Strategia rozwoju..., 2012).

Table 1. Selected objectives and measures of the Social Insurance Institution Development Strategy for 2013-2015

\begin{tabular}{|l|l|l|l|l|l|}
\hline \multicolumn{2}{|c|}{ Objective } & \multicolumn{3}{|c|}{ Measure } \\
\hline Code & \multicolumn{1}{|c|}{ Description } & \multicolumn{1}{|c|}{ Description } & Measure owner & Baseline level & $\begin{array}{l}\text { Target level- end } \\
\text { of 2015 }\end{array}$ \\
\hline K2 & $\begin{array}{l}\text { Customer service } \\
\text { improvement }\end{array}$ & $\begin{array}{l}\text { ZUS customer satisfaction } \\
\text { index }\end{array}$ & $\begin{array}{l}\text { DOK (Dziat } \\
\text { Obstugi Klienta } \\
- \text { Customer } \\
\text { Service Depart- } \\
\text { ment) }\end{array}$ & $3.93 \%$ & $\begin{array}{l}\text { Increase or main- } \\
\text { tenance }\end{array}$ \\
\hline
\end{tabular}


Pobrane z czasopisma Annales $\mathrm{H}$ - Oeconomia http://oeconomia.annales.umcs.pl

Data: 26/04/2023 14:13:17

60

ANNA H. MATUSZEWSKA

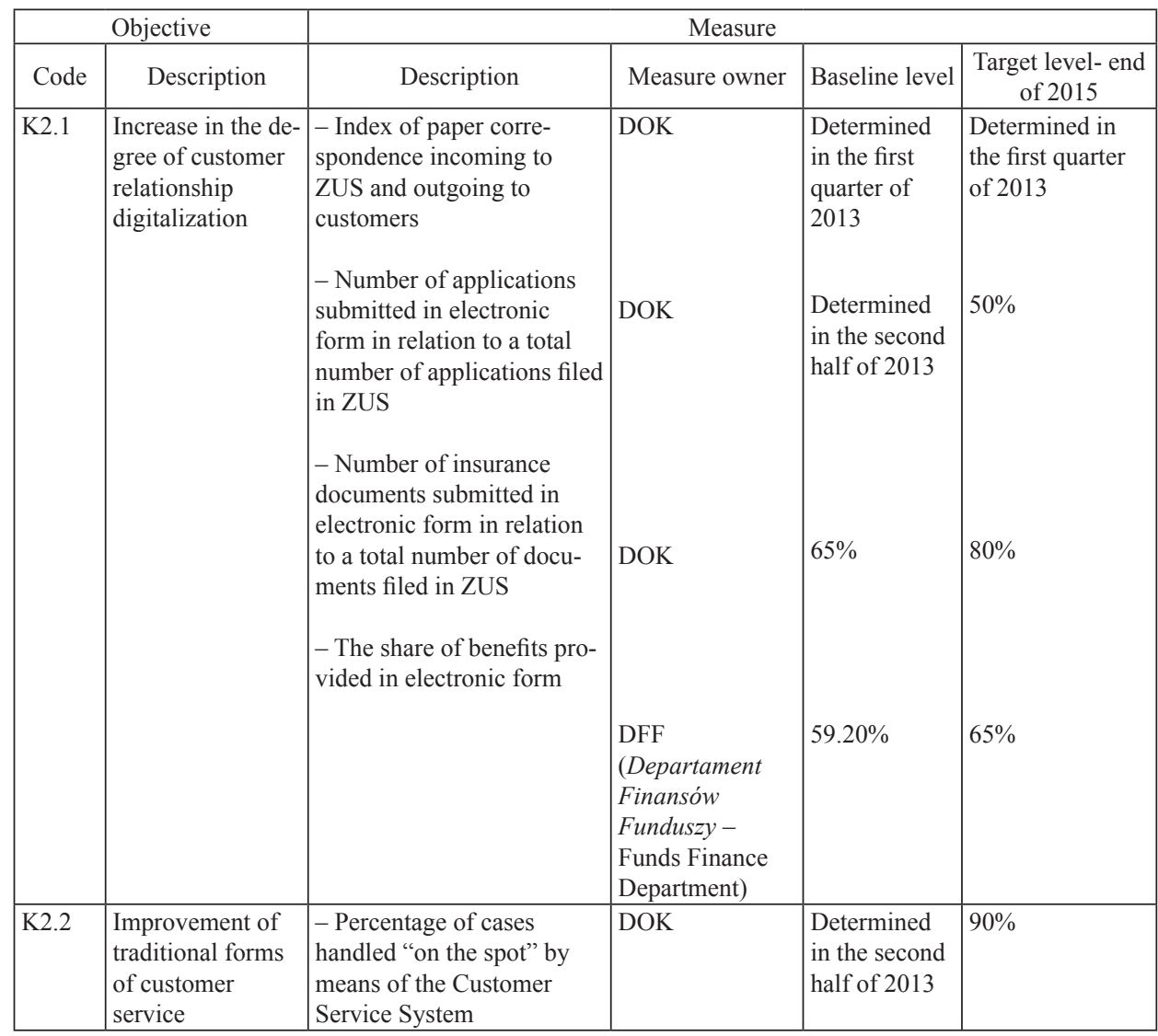

Source: Based on (Strategia rozwoju..., 2012).

Apart from the data indicated in Table 1, it is worth underlining the ultimate objective formulated within the Development strategy for the years 2013-2015 to increase confidence in ZUS as an institution (Strategia rozwoju ..., 2012). ZUS Strategy for the years 2016-2020 assumes further implementation of the objectives and its priority is to improve the standard of customer service.

Table 2. Objectives and measures of the Social Insurance Institution Strategy for 2016-2020

\begin{tabular}{|c|c|c|c|c|c|}
\hline \multicolumn{2}{|c|}{ Objective } & \multicolumn{3}{c|}{ Measure } \\
\hline Code & Description & \multicolumn{1}{|c|}{ Description } & Measure owner & $\begin{array}{l}\text { Baseline level - } \\
\text { end of 2014 }\end{array}$ & $\begin{array}{c}\text { Target level - end } \\
\text { of 2020 }\end{array}$ \\
\hline K1 & $\begin{array}{l}\text { Improvement } \\
\text { in the customer } \\
\text { service standard }\end{array}$ & $\begin{array}{l}\text { Overall satisfaction } \\
\text { index of ZUS customers }\end{array}$ & DOK & $\begin{array}{l}3.84 \% \\
\text { (baseline level } \\
\text { was determined } \\
\text { at the end of the } \\
\text { third quarter of } \\
2015)\end{array}$ & 4.2 \\
\hline
\end{tabular}


Pobrane z czasopisma Annales H - Oeconomia http://oeconomia.annales.umcs.pl Data: 26/04/2023 14:13:17

PRESENTATION AND ASSESSMENT OF PROVISIONS OF STRATEGIC DOCUMENTS ...

\begin{tabular}{|c|c|c|c|c|c|}
\hline \multicolumn{2}{|r|}{ Objective } & \multicolumn{4}{|c|}{ Measure } \\
\hline Code & Description & Description & Measure owner & $\begin{array}{c}\text { Baseline level - } \\
\text { end of } 2014\end{array}$ & $\begin{array}{l}\text { Target level - end } \\
\text { of } 2020\end{array}$ \\
\hline K1.1 & $\begin{array}{l}\text { Development of } \\
\text { electronic access } \\
\text { channels and pro- } \\
\text { viding an adequate } \\
\text { maturity level of } \\
\text { services provided } \\
\text { by means of these } \\
\text { channels }\end{array}$ & $\begin{array}{l}\text { - Degree of using } \\
\text { electronic services with } \\
\text { regard to submitting ap- } \\
\text { plications by customers } \\
\text { - Percentage of contri- } \\
\text { bution payers included } \\
\text { in the IPP software } \\
\text { (Interaktywny Ptatnik } \\
\text { Plus - Interactive Payer } \\
\text { Plus) at the highest level } \\
\text { of insurance documents } \\
\text { verification } \\
\\
\text { - Percentage of controls } \\
\text { of contribution payers } \\
\text { carried out involving } \\
\text { electronic exchange of } \\
\text { documents with contri- } \\
\text { bution payers }\end{array}$ & $\begin{array}{l}\text { DUS } \\
\text { (Departament } \\
\text { Ubezpieczeń } \\
\text { i Sktadek- } \\
\text { Insurance and } \\
\text { Contribution } \\
\text { Department) }\end{array}$ & $\begin{array}{l}60.22 \% \\
\text { (baseline level } \\
\text { determined } \\
\text { for } 31 \text { October } \\
2015)\end{array}$ & $\begin{array}{l}\text { Measure moni- } \\
\text { tored since } 2018\end{array}$ \\
\hline K1.2 & $\begin{array}{l}\text { Improvement in } \\
\text { traditional forms } \\
\text { of customer } \\
\text { service }\end{array}$ & $\begin{array}{l}\text { Efficiency of handling } \\
\text { cases "on the spot" in } \\
\text { the Customer Service } \\
\text { System (SOK) }\end{array}$ & DOK & $74 \%$ & $90 \%$ \\
\hline
\end{tabular}

Source: Based on (Strategia Zakładu..., 2015).

Development of electronic access channels and provision of an adequate maturity level of the services provided by means of these channels is an objective implemented by means of the Electronic Services Platform (Platforma Uslug Elektronicznych, PUE ZUS), which is the first e-institution in Poland. It is a real turning point, particularly from the point of view of those customers who, having access to the Internet, are able to deal with their insurance issues without the need to visit ZUS offices in person. It seems that in the era of developing the information society and electronic services, such solutions have become a standard. PUE ZUS works as an alternative form of contact with ZUS and it is a particularly useful tool for those who, for various reasons, give up traditional visits at ZUS offices and turn to electronic services (Niedziela, 2018, p. 141). Moreover, the number of people using PUE ZUS increases every year and the platform undergoes regular updates to offer new options and possibilities.

In January 2017, 1.7 million customers had their profile in PUE ZUS, while as of 31 December 2017 - the number increased to 2,032,090, with payers and 
professionals (bailiffs and doctors, who use PUE ZUS on a daily basis ${ }^{3}$ ) being the most active group of users. Systematically updated information about the number of the registered PUE ZUS profiles is available on its webpage - 3,430,861, as of 26 January $2019 .{ }^{4}$ An account at PUE ZUS allows the customers to access and analyze the data stored on their individual accounts in ZUS. They can as well use it to make an appointment at ZUS or check whether their application, for insurance, was submitted by their employers. What is particularly interesting, there is also a possibility to take advantage of a special calculator which calculates future pensions. The platform can also be used for submitting applications in the social program Family $500+$ (Rodzina 500+).

Despite the fact that customers use electronic services on a more and more regular basis, a conventional visit at a ZUS office is still the most common form of contact with the institution. Therefore, improvements in this area are also necessary, or probably mainly in this area. Customer service rooms have also been successively modernized to meet standards accepted for the entire organization: uniform décor, confidentiality while handling issues, and electronic queuing system. It also needs to be emphasized that the disabled are served in ZUS with particular care.

Adjusting the content of ZUS documents to its customers' knowledge was another undertaking, embarked on in 2016, whose aim was to improve the standard of customer service. The aim of this idea, called "Right from ZUS" ("Prosto z ZUS"), is to convert the complicated language of documents into a style that is comprehensible for people who do not know the legal jargon. ZUS President claims that " $(\ldots)$ simplifying the language is necessary in order to improve relations between the organization and its customers. It will fit the context of improving the image of ZUS, being a state organizational unit" (Niedziela, 2018, p. 141). As a result, 83 new and simplified forms were created and 10 ZUS simple language rules were introduced as a model for correspondence with individual customers. Moreover, standard letters for administrative procedures were prepared (decisions, certificates, notifications) and the language of brochures and leaflets for customers was simplified, together with the majority of articles on the ZUS webpage. Over 30,000 ZUS workers received professional training in the new standards.

The mechanism of building customers' satisfaction adapted by ZUS turned out to be efficient - in a study conducted by CBOS in 2017, ZUS received the highest scores among all the institutions included in the research. The problem in question was the quality of the services they provide assessed on a five-point scale - ZUS scored 4.4 points. $^{5} 64 \%$ of respondents were satisfied with the fact that their issues

3 Ibidem.

4 Available at www.zus.pl

5 The survey "Polak w urzędzie" ("A Pole at an office") was conducted on 2-12 November on a representative randomized sample, which included 1,016 adult Poles. Score 1 - "definitely negative", score 5 - "definitely positive". The results were published in Komunikat CBOS (CBOS Announcement) $173 / 2017$. 
were handled "on the spot", $98 \%$ claimed that they were served in a proper and reliable way, and $87 \%$ stated that enough attention and time were dedicated to them. Moreover, $93 \%$ of respondents assessed the level of competence of ZUS staff as very high (Rzeczpospolita ubezpieczonych..., 2018, p. 75).

Customer satisfaction - the goal initiated in the transformation strategy for the years 2010-2012 - was in a certain way a message that allowed for the more precision-oriented formulation of initiatives for the following years and a more precise evaluation of results. The improved customer service, the goal of the strategy for the years 2013-2015, was slightly modified and defined in the strategy for the years 2016-2020 as the improvement of the customer service standard. The performed activities aimed at providing customers with efficient, thorough and friendly customer service had the desired effect - in the IV quarter of 2018 almost $72 \%$ of the surveyed evaluated the quality of the service offered by ZUS as high or very high.

Pace and extent of the digitization correspond well with the wide-spread introduction of digital medical leaves, as of 1 December 2018. Before the end of November 2019 , more than 25 million e-leaves were issued, which makes up for $99.9 \%$ of all medical leaves issued. It is worth noting that, due to the introduction of innovative solutions and the direction towards the digitization of services, ZUS has won many prestigious awards. ${ }^{6}$

\section{Conclusions}

A still growing need for reflection on the organization and functioning of the Social Insurance Institution is expressed during numerous meetings, conferences and congresses. The mass media reports almost every day about unflattering situations which shed unfavorable light on the organization. Therefore, presentation of measures taken by ZUS for its customers, through steady work to gain public trust, is even more justified. However, these measures face various obstacles which threaten the achievement of objectives: external barriers, mainly related to the law - the number and dynamics of its changes, and internal ones, which include:

- lack of appropriate resources - financial, material, human, infrastructural,

- employees' resistance to changes,

- the fact that ZUS employees do not identify themselves with the institution,

- missing deadlines for implementing key initiatives (Strategia Zakładu ..., 2015).

The analysis of ZUS strategic documents, for the years 2010-2020, carried out in this article indicates and confirms due care taken to achieve its vision and mission,

6 Polish Innovation Award 2019 (Polska Nagroda Innowacyjności 2019) was awarded to ZUS for the introduction of services to clients. In November 2019, it was given the title of Symbol of the Innovation 2019 (Symbol Innowacyjności 2019), which is an award given to the entities offering public services to citizens. 
and thereby its objectives. ZUS is present in every citizen's life due to the insurance subject matter it deals with. Therefore, it should work in an efficient and reliable way, perform its tasks on time, and communicate with its customers in a way that is comprehensible for them. All these measures are conducive to improving the standard of customer service. Noteworthy, ZUS customers vary in gender, status, form of employment or running a business, and many other criteria, which may cause certain difficulties in recognizing real needs, finding optimal solutions, and implementing concrete solutions. These difficulties may influence the degree of achieving target levels of measures. Additionally, all objectives must be achieved in compliance with the rule of rational and transparent spending of public funds.

Surveys on customer satisfaction indicate that actions taken by ZUS have tangible results. ZUS has determined clear goals and directions for change, stipulated in the consecutively adopted and implemented strategies. It is clear that the next step for the customer service is to further develop electronic communication.

However, it does not change the fact that ZUS is still challenging the stereotype of being an ossified and ruthless institution which is hard to trust. That is why methodical work within the field of management and implementation control of strategic documents is necessary. In order to assure effectiveness of activities undertaken by the organization, systematic diagnosis of the implementation of its objectives is necessary to minimize the risk that they will not be achieved, as well as each and everyday assurance that it is the human being that is of utmost importance in the social insurance system.

\section{References}

Act of 13 December 1998 on the social insurance system (Journal of Laws of 2018, item 1076).

Blikle, A.J. (2013). Doktryna jakości. Rzecz o skutecznym zarządzaniu. Warszawa: Onepress.

Długookresowa Strategia Rozwoju Kraju. Polska 2030. Trzecia fala nowoczesności. Strategia rozwoju kraju 2020. (2013). Warszawa: Ministerstwo Administracji i Cyfryzacji.

Garvin, D. (2006). Budowanie organizacji uczącej się. In Harvard Business Review. Zarządzanie wiedzą. Gliwice: Wydawnictwo Helion.

Kotarbiński, T. (1975a). Hasło dobrej roboty. Warszawa: Wiedza Powszechna.

Kotarbiński, T. (1975b). Traktat o dobrej robocie. Wrocław: Zakład Narodowy im. Ossolińskich.

Krzakiewicz, K., \& Cyfert, Sz. (2015). Podstawy zarzadzania organizacjami Poznań: Wydawnictwo Uniwersytetu Ekonomicznego.

Letter 990100/0146/49/2018 of 19 March 2018 given to the author by the ZUS Customer Service Department.

Lewandowska, M. (2014). Dlaczego się zmieniamy, czyli co to jest New Public Management? Z życia ZUS, 4(160).

Niedziela, M. (2018) Zakład Ubezpieczeń Społecznych zmienia się dla klienta. In A. Matuszewska (red.), Kalisz: PWSZ im. Prezydenta Stanisława Wojciechowskiego.

Penc, J. (1999). Skuteczne zarządzanie organizacją. Łódź: Wyższa Szkoła Marketingu i Biznesu.

Robbins, S.P., \& DeCenzo, D.A. (2002). Podstawy zarządzania. Warszawa: Polskie Wydawnictwo Ekonomiczne. 
Pobrane z czasopisma Annales H - Oeconomia http://oeconomia.annales.umcs.pl

Data: 26/04/2023 14:13:17

PRESENTATION AND ASSESSMENT OF PROVISIONS OF STRATEGIC DOCUMENTS ...

Rzeczpospolita Ubezpieczonych. Historia ubezpieczeń społecznych w Polsce 1918-2018. (2018). Warszawa: ZUS.

Stoner, J.A.F., Freeman, R.E., \& Gilbert, D.R. (2001). Kierowanie. Warszawa: Polskie Wydawnictwo Ekonomiczne.

Strategia przeksztatceń Zakładu Ubezpieczeń Spotecznych na lata 2010-2012. (2010). Warszawa: ZUS.

Strategia rozwoju Zakladu Ubezpieczeń Społecznych na lata 2013-2015. (2012). Warszawa: ZUS.

Strategia Zaktadu Ubezpieczeń Społecznych na lata 2016-2020. (2015). Warszawa: ZUS.

Szymańska, K. (2015). Wprowadzenie do metod i technik zarządzania. In K. Szymańska (red.), Kompendium metod i technik zarzadzania. Teoria i ćwiczenia. Warszawa: Oficyna a Wolters Kluwer business.

Zawicki, M. (2011). Nowe zarządzanie publiczne. Warszawa: Polskie Wydawnictwo Ekonomiczne.

\section{Internet sources}

www.zus.pl 